\title{
Inventory and Distribution of Mango Mealybugs Species in Western Burkina Faso: Relative Abundance and Population Fluctuation
}

\author{
Karim Nébié1, Souleymane Nacro², Issoufou Ouédraogo', Dona Dakouo, \\ Lenli Claude Otoidobiga ${ }^{1}$ \\ ${ }^{1}$ Institut de l'Environnement et de Recherches Agricoles (INERA), Direction Régionale de Recherches \\ Environnementales et Agricoles de l'Ouest (DRREAO), Station de Farako-Bâ, Bobo-Dioulasso, Burkina Faso \\ ${ }^{2}$ Institut de l'Environnementet de Recherches Agricoles (INERA), Centre Régional de Formation et de \\ Recherches Environnementales et Agricoles de Kamboinsé, Ouagadougou, Burkina Faso \\ Email: snacro2006@yahoo.fr
}

Received 18 June 2016; accepted 23 July 2016; published 26 July 2016

Copyright (C) 2016 by authors and Scientific Research Publishing Inc.

This work is licensed under the Creative Commons Attribution International License (CC BY). http://creativecommons.org/licenses/by/4.0/

(c) (i)

\begin{abstract}
Rastrococus invadens was the only reported mealybug species on the mango tree in Western Burkina Faso. This study aimed at carrying out the inventory and showing the importance and distribution of other mealybug species associated with the mango tree. It was also important to determine the periods of abundance of these species vis-a-vis $R$. invadens. For this purpose, the density of mealybugs was assessed in three study sites (Toussiana, Bérégadougou and Orodara) in Western Burkina Faso. The observations were made from June 2014 to June 2015 at a frequency of $15 \pm$ 1 days. They focused on 20 leaves (5 leaves/cardinal point) levied on each mango tree. The species identified as Ferrisia virgata Cockerell and Icerya aegyptiaca Douglas were collected from mangos infested by $R$. invadens representing $98 \%$ - 99\% of the density of the observed mealybug species. The periods of abundance of $F$. virgata and $I$. aegyptiaca were respectively the dry season and the rainy season. The effect of temperature, relative humidity and rainfall on the populations of $F$. virgata and $I$. aegyptiaca was also discussed. These results highlight the distribution range of $F$. virgata and I. aegyptiaca worldwide including Burkina Faso. R. invadens was the main mealybug species on mango in Burkina Faso in general and in the Western region of the country in particular.
\end{abstract}

\section{Keywords}

Mango Mealybugs, Rastrococus invadens, Ferrisia virgata, Icerya aegyptiaca

How to cite this paper: Nébié, K., Nacro, S., Ouédraogo, I., Dakouo, D. and Otoidobiga, L.C. (2016) Inventory and Distribution of Mango Mealybugs Species in Western Burkina Faso: Relative Abundance and Population Fluctuation. Advances in Entomology, 4, 191-199. http://dx.doi.org/10.4236/ae.2016.43020 


\section{Introduction}

In Burkina Faso, the fruit sector is an important source of incomes for smallholders. More than half (58\%) of fruit growers are mango producers. Mango is the major fruit product (62.50\% of national production) in Burkina Faso [1]. Nearly $75 \%$ of the 400,000 tons of mangoes produced annually are provided by the Western region of the country. In this area, yield losses are partly associated with insect pests. Thus, many insect pests have been reported on the mango tree by [2]. But the main insect pests are fruit flies, mealybugs and termites [3]. Rastrococcus invadens Williams was the only mealybug species reported as a threat to the mango industry in Burkina Faso [3] [4]. This invasive species was accidentally introduced in West Africa in the 1980s [5]. In Burkina Faso, it was reported for the first time in Niangoloko at the border with Côte d'Ivoire before invading the entire Western region of the country [3]. With the emergence and spread of $R$. invadens, some investigations are undertaken in order to develop a sustainable control strategy. Thus, the populations of the insect pest were monitored from 2014 to 2015 in mango orchards [5]. At the same period, mealybug species complex was evaluated on mango trees. This study aimed at showing mealybugs species diversity but also at determining their period of abundance and their importance in relation to $R$. invadens.

\section{Methods}

\subsection{Study Sites}

This work was conducted in three mango producing provinces of Western Burkina Faso. These included Houet, Comoé and Kénédougou (Figure 1). This region is the $R$. invadens distribution area. Several locations were surveyed to identify and locate the importance and the distribution of any mealybug species present in the distribution area of $R$. invadens (Figure 1). The Western region of Burkina Faso enjoys a Sudan type tropical climate [6]. The rainy season lasts for 5 to 6 months from May to October with an annual total of more than $900 \mathrm{~mm}$. The annual average temperature rarely exceeds $35^{\circ} \mathrm{C}$.

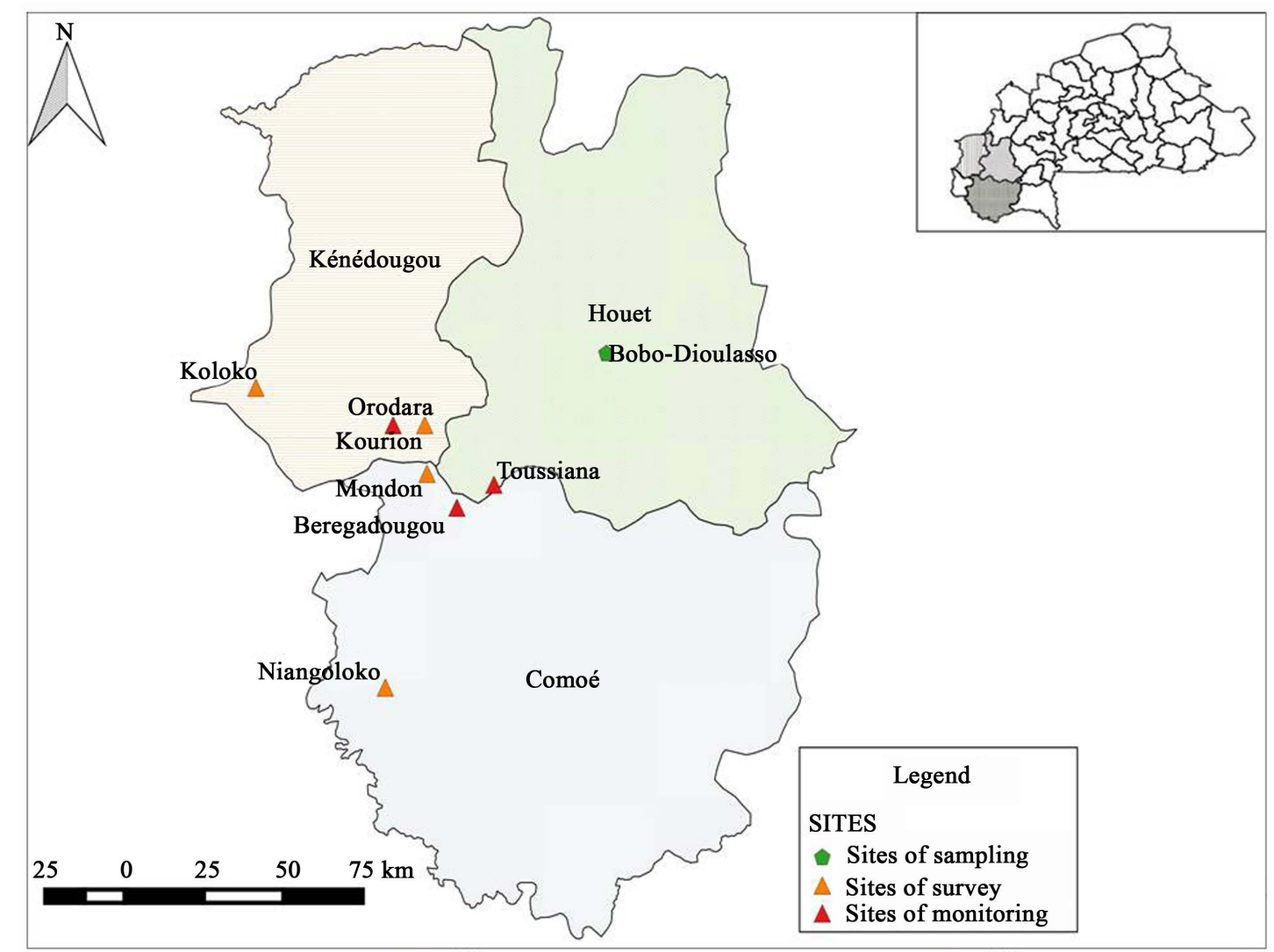

Figure 1. Inventory sites, distribution and monitoring of mango mealybugs in Western Burkina Faso. 


\subsection{Collection and Identification of Mealybugs in the Mango Tree}

Other mealybug species were collected during an inventory of $R$. invadens sources of infestation in BoboDioulasso city. The leaves, inflorescences and mango fruits infested with mealybugs have first been photographed. Mealybugs were then collected and kept in vials containing alcohol $70^{\circ}$. A preliminary screening made in the laboratory brought together the insects according to their shape, size and color of the different body parts. All specimens were sent to the International Institute of Tropical Agriculture (IITA), Cotonou (Bénin) for identification.

\subsection{Census of Mealybugs on Mango Infested by Rastrococcus invadens}

Following the identification results, seven mango orchards infested by $R$. invadens were prospected. Visual observations were made on the leaves, inflorescences and fruits of mango trees. The damage due to mealybugs was described. Specimens were collected and compared to a reference collection to confirm the identity of mealybugs and establish their distribution area.

\subsection{Evaluation of the Density of Identified Mealybug Populations}

The density of identified mealybugs was assessed on six mango trees selected in each of the following three locations: Bérégadougou, Orodara and Toussiana. Four mango varieties have been involved in this study. These are: Amélie, Kent, Lippens and green Mangot. These mangoes were kept insecticide free during the study. The observations were done from late June 2014 to mid-June 2015 at a frequency of $15 \pm 1$ days. They were carried out in situ on 20 leaves that is 5 leaves/cardinal point taken from the canopy of each mango tree. Live mealybugs (all stages included) of each species were counted by hand magnifiers.

\subsection{Statistical Analysis}

Data on the density of mealybugs were registered and organized by site, tree, and with Microsoft Excel software 2010. At each site, six trees were sampled for the evaluation of the mealybug densities. Observations were made on 120 leaves (20 leaves/tree) at each observation frequency. Thus, the average number of individuals of each species of mealybug was calculated by dividing the total number of mealybugs observed by the number of leaves (120). These values were expressed in number of mealybugs (all stages included)/leaf. They have been used to reflect the changing populations of mealybugsas observation frequencies. Throughout the study period, the total average was calculated to determine the proportion of each mealybug species. For statistical analysis purposes, the data were log transformed $(x+1)$ where $\mathrm{x}$ is the number of mealybugs. The transformed data were then pooled and subjected to multivariate analysis to assess the effect of abiotic factors on insect populations. Bilateral correlation analysis (thresholds of $5 \%$ and $1 \%$ ) was also made by the Pearson law to establish the level of relationship between the density of the mealybugs and the abiotic factors. These analyzes were performed with SPSS software (Statistical Package for the Social Sciences) statistics 22.

\section{Results}

\subsection{Mealybug Species Identified and Their Damage}

Two mealybug species have been identified on the mango trees infested by $R$. invadens. These are: Icerya aegyptiaca Douglas, 1890 (Hemiptera: Monophlebidae) and Ferrisia virgata Cockerell, 1893 (Hemiptera: Pseudococcidae). Icery aaegyptiaca infestations were mainly observed on leaves and twigs and very rarely on blossoms and fruit. On leaves, the bug colonized the midrib of the lower and upper parts (Photo 1).

Those of F. virgata were observed on the leaves, inflorescences and fruits. On leaves, the pest colonized both leaf surfaces through the main and secondary veins. On fruits, infestations begin with the stem and gradually invade the entire skin of the fruit (Photo 2).

\subsection{Distribution and Relative Abundance of Ferrisia virgata, Icerya aegyptiaca and Rastrococcus invadens}

The survey carried out in seven locations confirmed the presence of I. aegyptiaca and F. virgata on mango trees infested by $R$. invadens. These three mealybug species were seen together on the leaves, inflorescences and fruits 


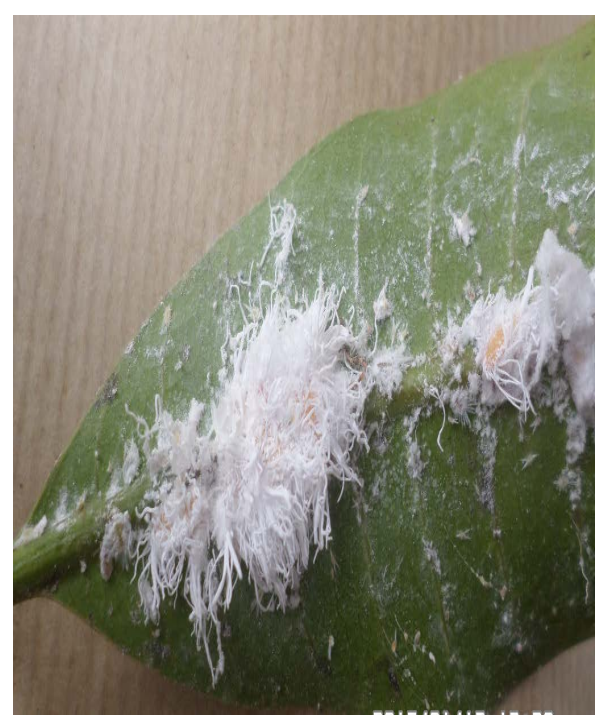

Photo 1. Colony of Icerya aegyptiaca on the main nervure of the lower surface of a mango leaf.

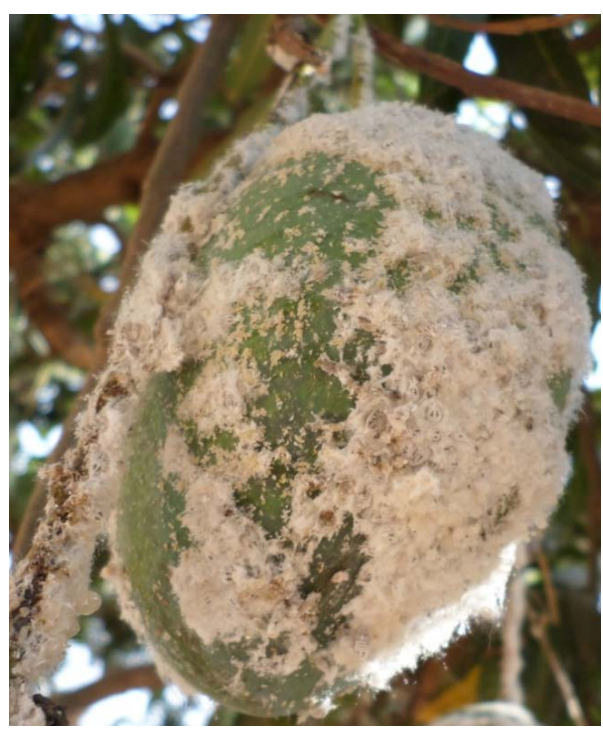

Photo 2. A mango infested by a colony of Ferrisia virgata.

of mango trees. After 24 observation sessions twice weekly, the sum of the average densities expressed in number of mealybugs/leaf has reached 1290 in Orodara. Those of Toussiana and Bérégadougou reached respectively 1031 and 714. The species $R$. invadens was more abundant than F. virgata and I. aegyptiaca in all study sites (Table 1). Rastrococcus invadens represented alone 98 to $99 \%$ of the sum of the average densities of mealybugs counted on the leaves of mango trees. Ferrisia virgata and I. aegyptiaca represented about $1 \%-2 \%$ of the population. Icerya aegyptiaca was more abundant than F. virgata in Bérégadougou and Orodara.

\subsection{Fluctuation of the Populations of Ferrisia virgata and Icerya aegyptiaca According to the Season}

On the three study sites, the density of populations of F. virgata and I. aegyptiaca remained very low (0 - 4 mealybugs/leaf) during the study period (Figures 2-4).

In Bérégadougou, I. aegyptiaca was dominant over F. virgata during the rainy season (May to October 2014 and May-June 2015). It was observed on average from 0.06 to 1.2 individuals /leaf for I. aegyptiaca against 0 to 0.25 for F. virgata (Figure 2). Icerya aegyptiaca populations reached abundance picks in mid-July, late August 2014 


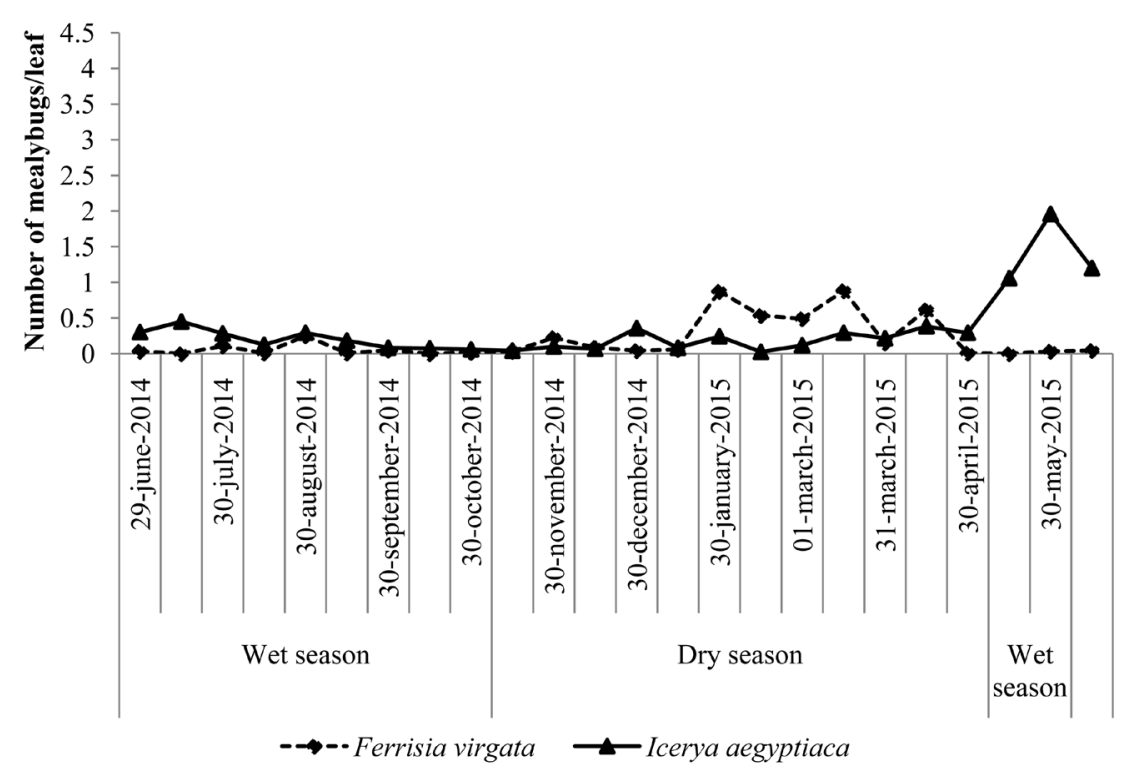

Figure 2. Evolution of the populations of Ferrisia virgata and Icerya aegyptiaca in Bérégadougou between June 2014 and June 2015.

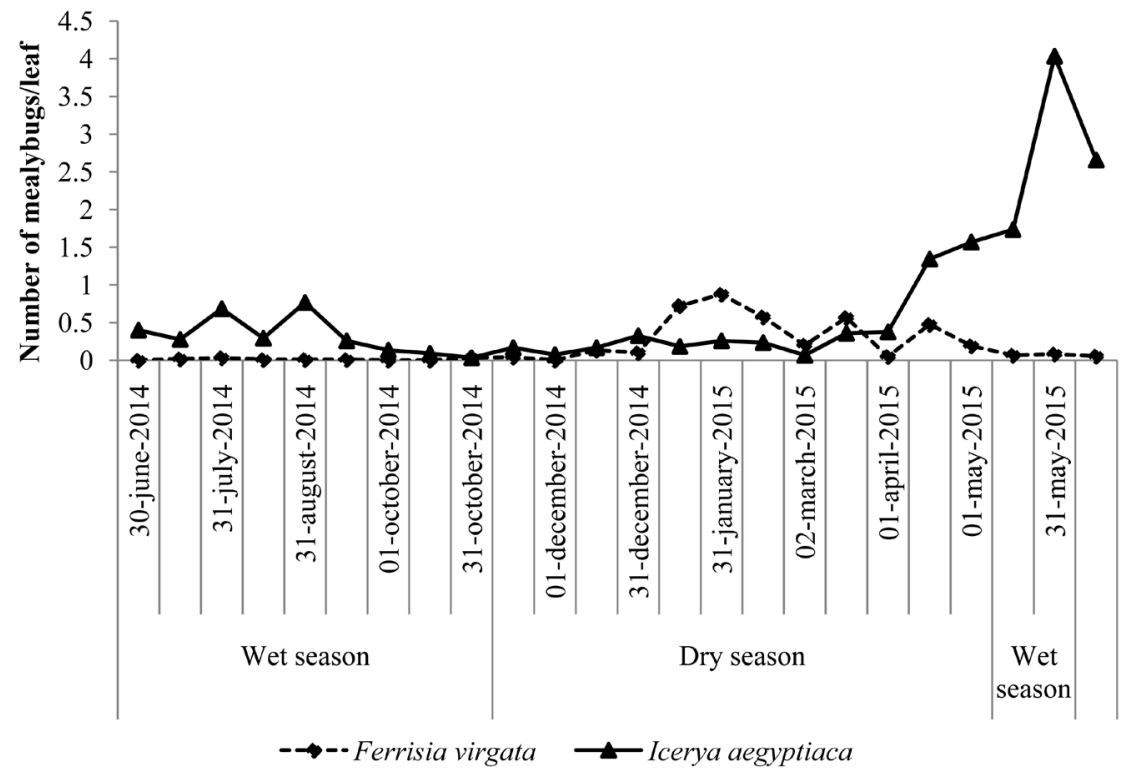

Figure 3. Evolution of the populations of Ferrisia virgata and Icerya aegyptiaca in Orodara between June 2014 and June 2015.

Table 1. Relative abundance (\%) of Ferrisia virgata, Icerya aegyptiaca and Rastrococcus invadens from June 2014 to June 2015 in three locations of Burkina Faso.

\begin{tabular}{|c|c|c|c|c|c|}
\hline \multirow{3}{*}{$\mathrm{N}^{\circ}$} & \multirow{3}{*}{ Family } & \multirow{3}{*}{ Species } & \multicolumn{3}{|c|}{ Location } \\
\hline & & & \multicolumn{3}{|c|}{ Relative abundance (\%) } \\
\hline & & & Bérégadougou & Orodara & Toussiana \\
\hline 1 & & Ferrisia virgata & 0.64 & 0.33 & 0.78 \\
\hline 2 & & Rastrococcus invadens & 98.20 & 98.39 & 98.92 \\
\hline 3 & Monophlebidae & Icerya aegyptiaca & 1.16 & 1.28 & 0.31 \\
\hline
\end{tabular}




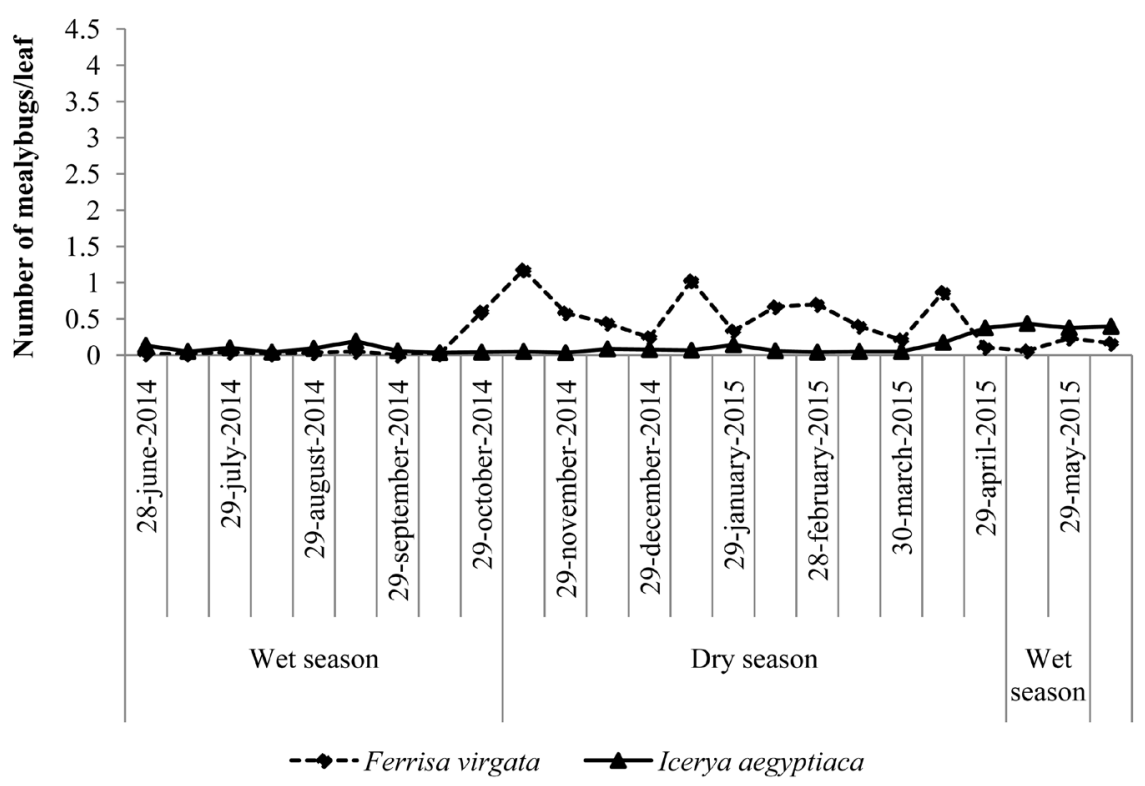

Figure 4. Evolution of the populations of Ferrisia virgata and Icerya aegyptiaca in Toussiana between June 2014 and June 2015.

and at the end in May 2015. Those of F. virgata were observed in late July and end-August 2014. During the dry season (December 2014-April 2015), F. virgata was more frequent than I. aegyptiaca with an average of 0.033 to 0.9 individuals/leaf against 0.04 to 0.38 individuals/leaf. Furthermore, $F$. virgata reached abundance picks in late November 2014, late January, mid-March and mid-April 2015. The abundance picks of I. aegyptiaca were observed in late December 2014 and late January 2015.

In the second study site (Orodara), I. aegyptiaca also prevailed over F. virgata during the rainy season (Figure 3). It was recorded on average from 0.03 to 4.03 individuals/leaf of $I$. aegyptiaca against 0 to 0.06 for $F$. virgata. The abundance picks of I. aegyptiaca were observed in late July, late August 2014 and at the end of May 2015. During the dry season, F. virgata was more frequent with an average density of .04 to 0.9 individuals/leaf against 0.06 to 0.4 individuals/leaf for I. aegyptiaca. The abundance picks of $F$. virgata were observed in late January and mid-April 2015.

On the third study site (Toussiana), I. aegyptiaca was more frequent during the rainy season with on average starting from 0.04 to 0.5 individuals/leaf against 0 to 0.23 individuals/leaf for $F$. virgata (Figure 4). The abundance picks of I. aegyptiaca were observed in late July, mid-September 2014 and mid-May 2015. Ferrisia virgata was more frequent during the dry season, with an average of 0.1 to 1.2 individuals/leaf against 0.03 to 0.14 individuals/leaf for I. aegyptiaca. The picks abundance of F. virgata were observed in mid-November 2014, midJanuary, late February and mid-April 2015.

\subsection{Effect of Abiotic Factors on the Populations of Ferrisia virgata and Icerya aegyptiaca}

Based on the analysis of the climate data collected from the three study sites, it appeared that the temperature, the relative humidity and the location have had a significant effect $(P<0.0001)$ on the populations of $F$. virgata and $I$. aegyptiaca.

The temperature and relative humidity significantly affected $(0.037 \leq P<0.0001)$ the populations of $I$. aegyptiaca (Table 2). A positive and significant correlation was observed between I. aegyptiaca and the temperature (Table 3).

Only the relative humidity significantly affected $(P<0.0001)$ the populations of $F$. virgata. This species density was significantly correlated with temperature, relative humidity, and rainfall. The correlation coefficient was positive for temperature and negative for relative humidity and rainfall.

\section{Discussion}

The surveys carried out in $R$. invadens habitats allowed the discovery of two mango native mealybugs species. 
Table 2. Results of multivariate analysis performed to show the effect of each abiotic factor on Ferrisia virgata and Icerya aegyptiaca in three locations of Western Burkina Faso.

\begin{tabular}{|c|c|c|c|c|c|c|c|}
\hline Source & Dependant variable & $\begin{array}{c}\text { Sum of squares } \\
\text { of type III }\end{array}$ & df & $\begin{array}{l}\text { Mean } \\
\text { square }\end{array}$ & $\mathrm{F}$ & Signification & $\begin{array}{c}\text { Partial } \\
\text { eta-square }\end{array}$ \\
\hline \multirow{2}{*}{ Corrected model } & Ferrisia virgata & $1.355^{\mathrm{a}}$ & 5 & 0.271 & 22.330 & $<0.0001$ & 0.215 \\
\hline & Icerya aegyptiaca & $1.477^{\mathrm{b}}$ & 5 & 0.295 & 16.301 & $<0.0001$ & 0.167 \\
\hline \multirow{2}{*}{ Constant } & Ferrisia virgata & 0.068 & 1 & 0.068 & 5.601 & 0.018 & 0.014 \\
\hline & Icerya aegyptiaca & 0.431 & 1 & 0.431 & 23.775 & $<0.0001$ & 0.055 \\
\hline \multirow{2}{*}{ Temperature } & Ferrisia virgata & 0.003 & 1 & 0.003 & 0.268 & 0.605 & 0.001 \\
\hline & Icerya aegyptiaca & 0.541 & 1 & 0.541 & 29.854 & $<0.0001$ & 0.068 \\
\hline \multirow{2}{*}{ Relative humidity } & Ferrisia virgata & 0.616 & 1 & 0.616 & 50.800 & $<0.0001$ & 0.111 \\
\hline & Icerya aegyptiaca & 0.097 & 1 & 0.097 & 5.357 & 0.021 & 0.013 \\
\hline \multirow{2}{*}{ Rainfall } & Ferrisia virgata & 0.000 & 1 & 0.000 & 0.013 & 0.908 & 0.000 \\
\hline & Icerya aegyptiaca & 0.001 & 1 & 0.001 & 0.058 & 0.809 & 0.000 \\
\hline \multirow{2}{*}{ Locations } & Ferrisia virgata & 0.101 & 2 & 0.051 & 4.183 & 0.016 & 0.020 \\
\hline & Icerya aegyptiaca & 0.850 & 2 & 0.425 & 23.440 & $<0.0001$ & 0.103 \\
\hline \multirow{2}{*}{ Error } & Ferrisia virgata & 4.950 & 408 & 0.012 & & & \\
\hline & Icerya aegyptiaca & 7.395 & 408 & 0.018 & & & \\
\hline \multirow{2}{*}{ Total } & Ferrisia virgata & 8.342 & 414 & & & & \\
\hline & Icerya aegyptiaca & 12.328 & 414 & & & & \\
\hline \multirow{2}{*}{ Corrected total } & Ferrisia virgata & 6.305 & 413 & & & & \\
\hline & Icerya aegyptiaca & 8.872 & 413 & & & & \\
\hline
\end{tabular}

${ }^{\mathrm{a}} \mathrm{R}$-two $=0.215$ (R-two adjusted $\left.=0.205\right) ;{ }^{\mathrm{b}} \mathrm{R}$-two $=0.167$ (R-two adjusted $=0.156$ ); ${ }^{\mathrm{c}}$ Computed with alpha $=0.05$.

Table 3. Level of correlation between the populations of Ferrisia virgate and Icerya aegyptiaca and the abiotic factors.

\begin{tabular}{|c|c|c|c|c|c|c|}
\hline & Rastrococcus invadens & Temperature & Relative humidity & Rainfall & Ferrisia virgata & Icerya aegyptiaca \\
\hline Rastrococcus invadens & 1 & & & & & \\
\hline Temperature & $-0.481^{* *}$ & 1 & & & & \\
\hline Relative humidity & $0.304^{* *}$ & $-0.287^{* *}$ & 1 & & & \\
\hline Rainfall & $0.451^{* *}$ & $-0.377^{* *}$ & $0.684^{* *}$ & 1 & & \\
\hline Ferrisia virgata & -0.075 & $0.152^{* *}$ & $-0.444^{* *}$ & $-0.328^{* *}$ & 1 & \\
\hline Icerya aegyptiaca & $-0.180^{* *}$ & $0.229^{* *}$ & 0.058 & 0.018 & -0.023 & 1 \\
\hline
\end{tabular}

${ }^{* * *}$ The correlation was positive at 0.01 level (bilateral).

These include F. virgata and I. aegyptiaca. So, this study reports for the first time on the existence of $F$. virgata and I. aegyptiaca in Burkina Faso. Ferrisia virgata, I. aegyptiaca and $R$. invadens were found on the leaves, the inflorescences and the fruits of infested mango. In addition, each species had a specific position on the leaves. Rastroccocus invadens and F. virgata colonize the lower and upper faces of the leaf through the main and secondary veins. Conversely, I. aegyptiaca colonizes the lower and upper faces of the leaf through the main veins. Ferrisia virgata was already reported in several countries in West Africa and throughout the world [7]-[10]. As for I. aegyptiaca, it was also observed in West Africa, Asia and Oceania [11]. Species diversity of mango mealybugs revealed in this study is relatively limited as compared to the 10 species of the same families reported on 
the mango tree in the North and Central regions of Benin [9]. Ferrisia virgata and I. aegyptiaca populations' densities were very low during the study period. However, [5] reported on the same trees and study sites an average density of 4 - 164 individuals/leaf for $R$. invadens over the same study period. These comparative results thus show that $R$. invadens is the main mango mealybug species in Western Burkina Faso. This result suggests that $R$. invadens being an invasive species accidentally introduced into West Africa in the 1980s [12] is more aggressive than the native species and thus was able to occupy their habitats. On the other hand, the mango tree could be a secondary host plant for F. virgata and I. aegyptiaca; which explains their low density as compared to $R$. invadens. However, there is no evidence yet to support such hypothesis. Ferrisia virgata and I. aegyptiaca are important pests of specific crops or mango in some countries. Thus, F. virgata is Cocoa Swollen Shoot vector Virus (CSSV) rife in West Africa on the cocoa tree Theobroma cacao L. [13] [14]. This pest is also the vector of the Pepper Yellow Mottle Virus (PYMoV) in black pepper [15]. This insect pest is also one of the three main mealybugs of cotton in India, Pakistan and Brazil [16]. In the case of Burkina Faso, it is not excluded that this insect pest may become a major pest on cotton. But a study has not been conducted in this direction. Icerya aegyptiaca is known as a pest on various plants. It causes serious damage to mango in Iran where it was accidentally introduced in 2013 [17]. In India, [18] reported a significant reduction in the growth of seedlings of teak, Tectonagrandis Lf. Considered as a quarantine pest in the United States, I. aegyptiaca was intercepted between 1995 and 2012. Eight interceptions have been made on a variety of hosts from many countries. Abundant populations of $F$. virgata and I. aegyptiaca were alternately depending on the season in all study sites. Icerya aegyptiaca and F. virgata probably share the same food resource at different times of the year. This reduces a possible interspecific competition. Thus, the abundance of $F$. virgata periods were observed in the dry season (November to April) while those of I. aegyptiaca had lasted from May to October (rainy season). The rainy period is the period of abundance of $R$. invadens established by [5] on the same study sites. The relative humidity and temperature are the main abiotic factors that affected the populations of $F$. virgata and I. aegyptiaca. There is a significant and negative correlation between the populations of $F$. virgata with relative humidity and rainfall. However, populations of I. aegyptiaca were significantly and positively correlated with temperature.

\section{Conclusion}

During this study, two mealybugs native species were inventoried on the mango tree in Western Burkina Faso. These include $F$. virgata and I. aegyptiaca. These species coexist with $R$. invadens on the mango tree. The results of this study inform the scientific community on the distribution range of $F$. virgata and I. aegyptiaca worldwide including Burkina Faso. These two native mealybugs species were less abundant than $R$. invadens which remained the main mealybug species. Rastroccocus invadens exerts a trophic pressure on native mealybug species causing significant damage to the mango tree. This shows the need to explore opportunities for sustainable control of this insect pest. But it is important to consider the indigenous species of mealybugs in the control strategy. The management of these mealybugs species needs additional research on their host plants and their natural enemies.

\section{Acknowledgements}

We thank the West Africa Agricultural Productivity Programme (WAAPP) for funding this study. We extend our gratitude to Dr. Georg Georgen from IITA for its technical support in identifying the insect specimens. Our thanks also go to the technicians Adama Sow, Sanon Zézouma and Boukary Ouédraogo for their support in the field.

\section{References}

[1] MAH (2011) Rapport d'analyse du module arboriculture phase 2: RGA 2008. Bureau Central du Recensement Général de l'Agriculture (Ed.), Ministère de l'Agricultureet de l'Hydraulique, Ouagadougou, Burkina Faso, 252 p + annexes.

[2] Ouédraogo, S.N. (2002) Etude diagnostique des problèmes phytosanitaires du manguier (Mangifera indica L.), de l’oranger (Citrus sinensis (L.) Osbeck) et du mandarinier(Citrus reticulata Blanco) dans la province du Kénédougou. Mémoired’Ingéniorat de Développement Rural, Opt. Agronomie, Univ. Polytechnique de Bobo-Dioulasso, Burkina Faso, 95 p.

[3] Dakouo, D., Otoidobiga, L.C., Ouédraogo, N.S., Guira, M., Dabiré, R. and Kambou, G. (2011) Rapport de synthèse des activitésconduites pour la luttebiologiquecontre les insectesravageurs du manguier. Project PADL/CLK, INERA, Programme CMFPT, Bobo-Dioulasso, Burkina Faso, 33 p.

[4] Hala, N., Kehe, M. and Allou, K. (2004) Incidence de la cochenillefarineuse du manguier Rastrococcus invadens 
Williams, 1986 (Homoptera: Pseudococcidae) en Côte d’Ivoire. Agronomie Africaine, 16, 29-36.

[5] Nébié, K., Nacro, S., Otoidobiga, L.C., Dakouo, D. and Somda, I. (2016) Population Dynamics of the Mango Mealybug Rastrococcus invadens Williams (Homoptera: Pseudococcidea) in Western Burkina Faso. American Journal of Experimental Agriculture, 11, 1-11. http://dx.doi.org/10.9734/AJEA/2016/24819

[6] Lerebours, P.A., Menager, M.-T., et al. (2005) Atlas de l’Afrique: Burkina Faso. Les éditions du Jaguar, Groupe Jeune Afrique, Paris, France, 62 p.

[7] CAB International (1966) Ferrisia virgata [Distribution Map]. Distribution Maps of Plant Pests, June. CAB International, Wallingford, UK, Map 219.

[8] Ben-Dov, Y. (1994) A Systematic Catalogue of the Mealybugs of the World (Insecta: Homoptera: Coccoidea: Pseudococcidae and Putoidae) with Data on Geographical Distribution, Host Plants, Biology and Economic Importance. Intercept Limited, Andover, UK, 686 p.

[9] Germain, J.-F., Vayssieres, J.-F. and Matile-Ferrero, D. (2010) Preliminary Inventory of Scale Insects on Mango Trees in Benin. Entomologia Hellenica, 19, 124-131.

[10] Muniappan, R., Watson, G.W., Vaughan, L., Gilbertson, R. and Noussourou, M. (2012) New Records of Mealybugs, Scale Insects, and Whiteflies (Hemiptera: Sternorrhyncha) from Mali and Senegal. Journal of Agricultural and Urban Entomology, 28, 1-7. http://dx.doi.org/10.3954/1523-5475-28.1.1

[11] CABI and EPPO, 2003. Iceryaaegyptiaca. [Distribution map]. Distribution Maps of Plant Pests ( $1^{\text {st }}$ revision), December. Wallingford, UK: CAB International, Map 221.

[12] Neuenschwander, P., Boavida, P., Bokonon-Ganta, A.H., Gado, A. and Herren, H.R. (1994) Establishment and Spread of Gyranusoideatebygi Noyes and Anagyrusmangicola Noyes (Hymenoptera: Encyrtidae), Two Biological Control Agents Released against the Mango Mealybug Rastrococcus invadens Williams (Homoptera: Pseudococcidae) in Africa. Biocontrol Science and Technology, 4, 61-69. http://dx.doi.org/10.1080/09583159409355313

[13] Kouakou, K., Kébé, B.I., Kouassi, N., Anno, A.P., Aké, S. and Muller, E. (2011) Impact de la maladievirale du swollen shoot du cacaoyersur la production de cacao en milieu paysan à Bazré (Côte-d’Ivoire). Journal of Applied Biosciences, 43, 2947-2957.

[14] Obodji, A., N’Guessan, W.P., N’Guessan, K.F., Seri-Kouassi, B.P., Aboua, L.R.N., Kébé, I. and Aka, R. (2015) Inventory of the Mealybug Species Associated with the Cocoa Tree (Theobroma cacao L.) in Four Producing Areas Infected with the Swollen Shoot Disease in Côte d'Ivoire. Journal of Entomology and Zoology Studies, 3, 312-316.

[15] Boari, A.J., Ollveira, A.C.S., Prado, E., Pantoja, K.F.C. and Souza, C.M. (2010) Ferrisia virgata (Cockerell): Vetora do Piper yellow mottle virus da pimenteira doreino. Horticultura Brasileira, 28, 957-962.

[16] Oliveira, M.D., Silva-Torres, C.S.A., Torres, J.B. and Morais Oliveira, J.E. (2014) Population Growth and Within-Plant Distribution of the Striped Mealybug Ferrisiavirgate (Cockerell) (Hemiptera: Pseudococcidae) on Cotton. Revista Brasileira de Entomologia, 58, 71-76. http://dx.doi.org/10.1590/S0085-56262014000100012

[17] Moghaddam, M., Esfandiari, M. and Khosravi, M. (2015) First Record of Icerya aegyptiaca (Hemiptera: Coccoidea: Monophlebidae) from Iran. 1st Iranian International Congress of Entomology, Tehran, 25-31 August 2015, 42 p.

[18] Senthilkumar, N. and Barthakur, N.D. (2005) A Record of Egyptian Fluted Scale, Icerya aegyptiaca (Douglas) on Teak in Assam. Insect Environment, 11, 31-32. 


\section{Submit or recommend next manuscript to SCIRP and we will provide best service for you:}

Accepting pre-submission inquiries through Email, Facebook, LinkedIn, Twitter, etc.

A wide selection of journals (inclusive of 9 subjects, more than 200 journals)

Providing 24-hour high-quality service

User-friendly online submission system

Fair and swift peer-review system

Efficient typesetting and proofreading procedure

Display of the result of downloads and visits, as well as the number of cited articles

Maximum dissemination of your research work

Submit your manuscript at: http://papersubmission.scirp.org/ 